\title{
HUNGARIAN INTERNATIONAL MIGRATIONS IN THE CARPATHIAN BASIN, 2011-2017
}

\author{
ÁRON KINCSES $S^{l}$
}

\begin{abstract}
International migration into Hungary is markedly differentiated into two types: that due to global migration, and that due to processes ongoing between Hungary and its neighboring countries, the latter which date back a long time. The main characteristic of international migration in Hungary is that the largest part of the immigrant population is of Hungarian nationality. Population movements in the late 1980s and early 1990s made it clear that the demographic processes taking place in the Hungarian linguistic community despite the fragmentation occurring in 1918, and nearly 100 years of differentiated development - can only be fully understood if we examine them together as a single process. It is important to recognize that demographic processes within and outside of the current border are similar in nature. All that is happening in Hungary is only one part of the demographic processes of the entire Hungarian language community. The migration processes described in the paper would have a significant impact on the ethnic spatial structure of the Hungarians in the Carpathian Basin were the number of members of other ethnicities not similarly decreasing. Strengthening the number of people staying in their home country and increasing the number of return migrations and the fertility rate of local Hungarians could all be partial solutions to the problem of population decline.
\end{abstract}

KEYWORDS: Demography, International migration, spatial statistics, Carpathian-Basin

1 Áron Kincses, $\mathrm{PhD}$. is Deputy President at the Statistics Directorate of the Hungarian Central Statistical Office, email: aron.kincses@ksh.hu. This research was prepared with support from the Bolyai János Research Scholarship. 


\section{INTRODUCTION}

Much more is being said about Hungary's emigrants these days (Blaskó et al. 2016; Siskáné et al, 2017; Egedy, 2017) than about foreigners arriving legally to Hungary, or about Hungarians emigrating from the other countries of the Carpathian Basin. This paper analyses the intersection of the two latter phenomena, focusing on settlers from the Carpathian Basin arriving to Hungary. The study zooms into the present situation of international migration in Hungary and introduces the foreign population living in Hungary in numbers, as well as relevant socio-demographic and economic characteristics from the perspective of the source and target territories, thereby revealing the source areas of migration and the impact on the Hungarian population in the Carpathian Basin. The analysis interprets those involved in international migration in broad terms; as such, it is not solely focused on the movement of foreign citizens, but rather examines the effects of migration in relation to naturalized Hungarians born abroad.

\section{THE FRAMEWORK FOR THE ANALYSIS, THE DATA SOURCES}

There are several types of data sources about foreign nationals, mostly in the shape of administrative records. The latter include registers created by administrative organizations to support the implementation of their own statutory administrative tasks (Gárdos et al., 2008). In these cases, statistical and research needs do not primarily determine the concept and the content nor the reference time of data and definitions. Another difficulty is that the content and structure of such registers may suffer changes as a result of changes in legislation. All this means that, in some cases, it is difficult to obtain information directly from these data systems to meet statistical needs.

The advantage of census data over administrative data is that everyone can be linked to their habitual place of residence, along with all the variables included in related surveys. However, this information is not available as often as in administrative records. Surveys have also been carried out of Hungarian citizens who habitually live within the national territory, and of those who stay abroad only temporarily (12 months or fewer); moreover, foreign nationals and stateless persons who remain within the country's territory for a given period of time are also listed. Among the foreign nationals are not included the members of diplomatic bodies and their family members, members of foreign armed forces, as well as people visiting the country for the purposes of tourism, business meetings, etc. 
In this paper, I have used these two types of statistical data sources. I worked with 2011 and 2017 stock data from the Hungarian migration databases as they are relevant to the topic (the Ministry of Interior's Records of Foreign Residents, and censuses). The data underlying the analyses were not directly available, thus I had to make use of separate classifications for the assessment of territorial impacts. Currently, country classification is automated in administrative sources, and the list of foreign settlements posed a number of challenges: typing errors, instructions, and city names in different languages made progress difficult. ${ }^{2}$

Both data sources contain information that is missing from the other file (the census contains data related to education and economic activity which are not part of the Ministry of Interior's database; however, the administrative database contains details of birth settlements). For this reason, it was necessary to link both files. ${ }^{3}$ To this end, we employed a multistage key system using sex, year, and month of birth, name of settlement, public domain, and house number information. Where necessary, I used a rate estimate.

\section{INTERNATIONAL MIGRANTS LIVING IN HUNGARY}

\section{Quantities and nationalities}

Current global migration trends have also been experienced in Hungary: the foreign population living in the country is composed of people from 175 different countries. The proportion of people from Europe is steadily decreasing: while $89 \%$ of foreigners arrived from the European continent in 1995, this proportion had decreased to $65 \%$ by 2017 .

2 Just a few examples:

- The village of yore of Székelyhidegkút (Vidacutu Român in Romanian, Kaltenbrunnen in German) is today a village in Romania, in Harghita County. It emerged from the unification of Magyarhidegkút and Oláhhidegkút in 1926. The northern part of the village is Hungarian — the western part of Oláh-hidegkút, currently a part of the Hidegkút settlement. Hidegkút (Vidăcut in Romanian) is a village in Romanian Harghita County. It belongs administratively to Székelyandrásfalva/Sacel.

- Horthyvára: Máriamajor (Степановићево/Stepanovićevo in Serbian; between 1941 and 1944 known as Horthyvára; in 1941called Bácshadikfalva for a short period) today belongs to the Újvidék/Novy Sad township in Serbia in Vojvodina, in the Southern-Bácska district.

3 Marcell Kovács, Director of the Population Census and Demographic Statistics Department, and his experts, Zita Ináncsi and János Novák, provided assistance essential to this work. I hereby sincerely thank them for their support. 
At the same time, Hungary is not considered a typical host country in a global sense (Hatton et al. 2005; Krugman et al. 1996). On the one hand, the volume of migration and proportion in relation to the resident population is considerably smaller than it is in larger host countries; on the other, the prevailing global migration trends have only had a minor impact. Hungary (albeit to a decreasing extent) continues to be a target for Europeans, but rather as part of short-distance international migration.

Figure 1 Proportion of population born abroad in individual countries, 2017*

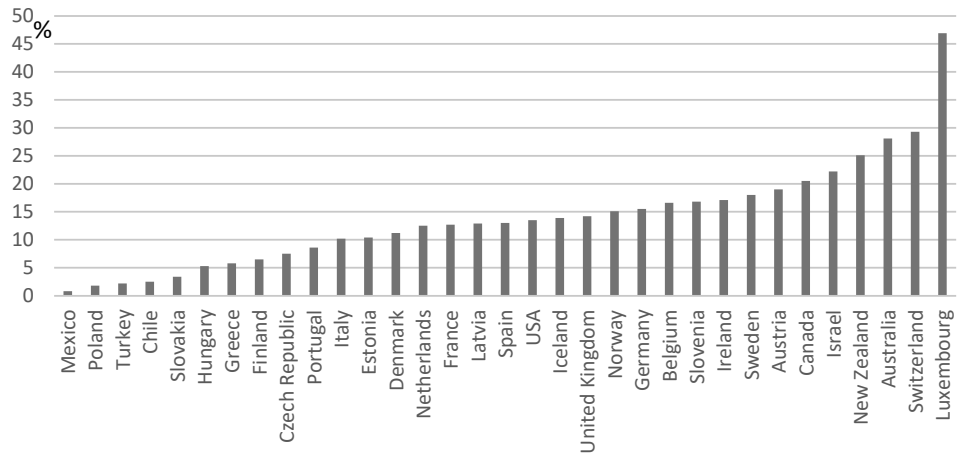

Source: OECD, SOPEMI, 2018; *: For Poland data is only available for the year 2011

Within Europe, the importance of neighboring countries is tied to crossborder linguistic and cultural relations. Thus, the consequences of the peace treaties that brought an end to World War I and World War II are still decisive in the migration processes of the Carpathian Basin today (Tóth 2005). As such, one can distinguish between two layers of international migration to Hungary: global, and Carpathian-Basin-origin-based movements, each involving groups of migrants with different characteristics.

International migrants living in Hungary are often examined in simplified terms as foreign citizens residing in Hungary. Nevertheless, the population involved in migration is much larger and its structure much more nuanced.

If we examine the previously described population only, we find that the number of foreign nationals in $2011(143,197)$ had increased by only $5.5 \%$ by 2017 , when 151,132 foreign nationals were living in Hungary. Thanks to global migration trends, in 2017, for example, more Chinese citizens were residing in Budapest than Romanians. However, this data needs further explanation. 
When examining the effects and extent of immigration, we must not forget the effects of naturalization: i.e. Hungarian citizens who were born abroad but who reside in Hungary. Their number significantly exceeds that of foreign nationals. Together, the two groups represent the target population to be examined: the population of foreign origin living in Hungary (the group is thus composed of foreign citizens and Hungarian citizens born abroad). Within this group, the number of foreign citizens is steadily declining: from $37 \%$ in 2011 to $29 \%$ in 2017.

In 2017, the "population of foreign origin" living in Hungary was 521,258 (an increase of 33\% since 2011). Those emigrating Hungarians who had returned to live in Hungary (127,000 people) are not included in this figure for the target population. These numbers counter the statement that Hungary's international migration balance is negative (Melegh 2015; Juhász et al. 2017).

At the same time, it is important to note that the majority of naturalized migrants arrive from neighboring countries. In 2011, 288,024 people living in Hungary had arrived from the Carpathian Basin countries. By 2017, their number had increased by $22 \%$ (to 352,506 people, of which 313,000 were Hungarian). Today, the number of people born in Romania living in Hungary is greater than the total population of Debrecen, the second largest settlement in the country. During the period under review, migration from neighboring countries rose dynamically, the largest share of which was attributable to Ukrainian migrants $(81 \%)$.

Table 1 Hungarian citizens born abroad and foreign nationals by major countries and regions

\begin{tabular}{c|c|c|c|c|c|c}
\hline \multirow{2}{*}{$\begin{array}{c}\text { Country of } \\
\text { citizenship/ } \\
\text { place of } \\
\text { birth }\end{array}$} & $\begin{array}{c}\text { Foreign } \\
\text { citizens }\end{array}$ & $\begin{array}{c}\text { Hungarians } \\
\text { born abroad }\end{array}$ & $\begin{array}{c}\text { Total } \\
\text { population } \\
\text { of foreign } \\
\text { origin }\end{array}$ & $\begin{array}{c}\text { Foreign } \\
\text { citizens }\end{array}$ & $\begin{array}{c}\text { Hungarians } \\
\text { born abroad }\end{array}$ & $\begin{array}{c}\text { Total } \\
\text { population } \\
\text { of foreign } \\
\text { origin }\end{array}$ \\
\hline Romania & 38574 & 139093 & 177667 & 24040 & 182387 & 206427 \\
\hline Germany & 16987 & 7294 & 24281 & 18627 & 16039 & 34666 \\
\hline Slovakia & 8246 & 25195 & 33441 & 9519 & 17376 & 26895 \\
\hline Austria & 3936 & 2897 & 6833 & 4021 & 7102 & 11123 \\
\hline EU28 & $\mathbf{8 5 4 1 4}$ & $\mathbf{1 8 3 7 6 1}$ & $\mathbf{2 6 9 1 7 5}$ & $\mathbf{7 6 2 7 0}$ & $\mathbf{2 4 8 5 2 4}$ & $\mathbf{3 2 4} \mathbf{7 9 4}$ \\
\hline Ukraine & 11820 & 23953 & 35773 & 5774 & 59272 & 65046 \\
\hline Serbia & 7752 & 21306 & 29058 & 2312 & 37497 & 39809 \\
\hline Europe & $\mathbf{1 1 2 5 2 2}$ & $\mathbf{2 3 7 7 8 5}$ & $\mathbf{3 5 0 3 0 7}$ & $\mathbf{9 9 1 9 4}$ & $\mathbf{3 5 0 7 5 6}$ & $\mathbf{4 4 9 9 5 0}$ \\
\hline total & 8852 & 939 & 9791 & 19111 & 415 & 19526 \\
\hline China & & & & &
\end{tabular}




\begin{tabular}{c|c|c|c|c|c|c}
\hline Asia total & 22304 & 4760 & 27064 & 39937 & 6539 & 46476 \\
\hline $\begin{array}{c}\text { America } \\
\text { total }\end{array}$ & 4743 & 3785 & 8528 & 5397 & 9149 & 14546 \\
\hline Africa total & 2853 & 1190 & 4043 & 5985 & 2398 & 8383 \\
\hline $\begin{array}{c}\text { Australia } \\
\text { and } \\
\text { Oceania }\end{array}$ & 775 & 350 & 1125 & 619 & 1284 & 1903 \\
\hline Total & 143197 & 247870 & 391067 & 151132 & 370126 & 521258 \\
\hline
\end{tabular}

Source: Hungarian Central Statistical Office (HCSO)

\section{Demographic, educational, and labor market characteristics}

Most studies point out that, in Hungary, the foreign population is younger than the autochthonous, indigenous population (Gödri 2012); thus, migration has a rejuvenating effect. This statement is true of foreign citizens (38.8 years, average age), particularly for women. However, Hungarian nationals born abroad are older (on average, 43.9 years old) than local residents (41.7 years). During the years under review, the average age of the foreign-born population decreased significantly (from 47.1 in 2011 to 42.6 years old). Behind this is the gradual loss (caused by death) of immigrants who arrived after the regime change and who have since grown old. The population not born in Hungary has fewer children, and overall a greater proportion of people of an economically active age. This holds particularly true for foreign citizens.

Figure 2 Resident population and the population of foreign origin by age group, January 1, 2017

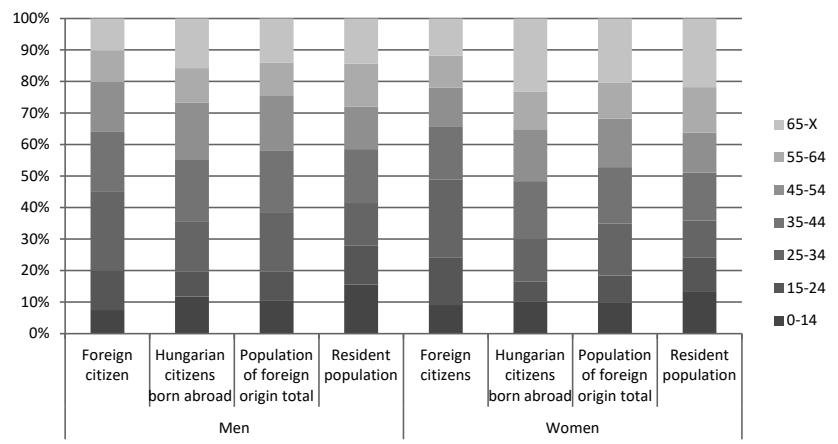


The level of education of the population of foreign origin is higher than that of those born in Hungary: in 2017, the percentage of foreigners (24 years old and older) having a higher education diploma was almost $46 \%$ and it was more than one third among Hungarian citizens born abroad. There are significant differences in education levels, which can be largely traced back to differences in age structure.

Figure 3 Population of residents and those of foreign origin (25 years old and older) by education level, January 1, 2017

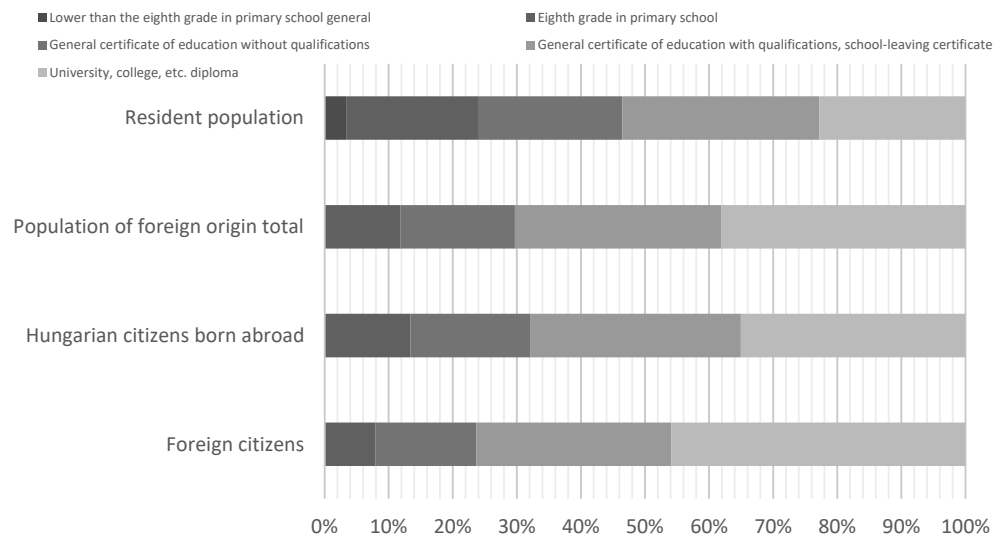

Source: Author's calculation, based on HCSO database

An association can be made between the education level and the high employment rate of international migrants since the change of regime in Hungary. The tendency in recent years has been for the economic activity of the resident population to approach that of the population of foreign origin, their unemployment rate of the latter already being higher than that of the other two groups under examination. Within the group of dependents, one tenth of the population are full-time students, while the share of international migrants is significantly larger, ranging from 14 to $23 \%$. 
Table 2 Distribution of 25-64 year old international migrants and residents by economic activity, 2017

\begin{tabular}{l|c|c|c|c}
\hline \multicolumn{1}{c|}{ Economic activity } & $\begin{array}{c}\text { Foreign } \\
\text { citizens }\end{array}$ & $\begin{array}{c}\text { Hungarian } \\
\text { citizens born } \\
\text { abroad }\end{array}$ & $\begin{array}{c}\text { Total of } \\
\text { population of } \\
\text { foreign origin }\end{array}$ & $\begin{array}{c}\text { Resident } \\
\text { population }\end{array}$ \\
\hline Employed & 81.3 & 80.2 & 80.5 & 75.1 \\
\hline Unemployed & 3.8 & 3.7 & 3.8 & 3.5 \\
\hline $\begin{array}{l}\text { Total. economically active } \\
\text { population }\end{array}$ & 85.1 & 83.9 & 84.3 & 78.6 \\
\hline Economically inactive & 7.6 & 11.0 & 10.0 & 17.3 \\
\hline Dependent & 7.3 & 5.1 & 5.7 & 4.1 \\
\hline $\begin{array}{l}\text { Total. economically inactive } \\
\text { population }\end{array}$ & 14.9 & 16.1 & 15.7 & 21.4 \\
\hline Total & 100.0 & 100.0 & 100.0 & 100.0 \\
\hline
\end{tabular}

Source: $\mathrm{HSCO}$

\section{Territorial characteristics}

In the case of internal migration, it is true that social groups with better labor market positions migrate to regions that feature stronger economic indicators, a better image, and a higher position in the settlement hierarchy (Bálint et al. 2017).

These findings are only partially characteristic of international migration. In addition to income opportunities, a more important role is played by the territorial location of destinations and the natural environment (Dövényi 2011). Therefore, the spatial distribution of the population of foreign origin is different to the distribution of the Hungarian-born population and their influence is greater in the areas they dwell in than in the national context.

Looking through the lens of migration, three regions stand out in which the aforementioned migrant groups are permanently present generally in larger numbers and proportions in Hungary: Central Hungary, the areas near the border, and the Lake Balaton region.

Budapest and Pest County attract people from a greater distance, and the majority of non-European foreigners live here. Many of them are employed, are younger on average, and more highly educated. It is thus primarily economically active, highly qualified foreign citizens who settle down here. Over the past ten years, Budapest has become a global destination for migration.

In Hungary, where the majority of foreign citizens still continue to arrive from neighboring countries, the location of target areas also plays a decisive role in the distribution of the foreign population. Therefore, in the choice of a new place of residence, border regions also play an important role, in addition to economic 
centers. In these settlements, the composition of citizenship is not as diverse; rather, most foreigners simply arrive from the other side of the border.

Figure 4 Distribution of population of foreign origin and resident population by current residence status, 2017

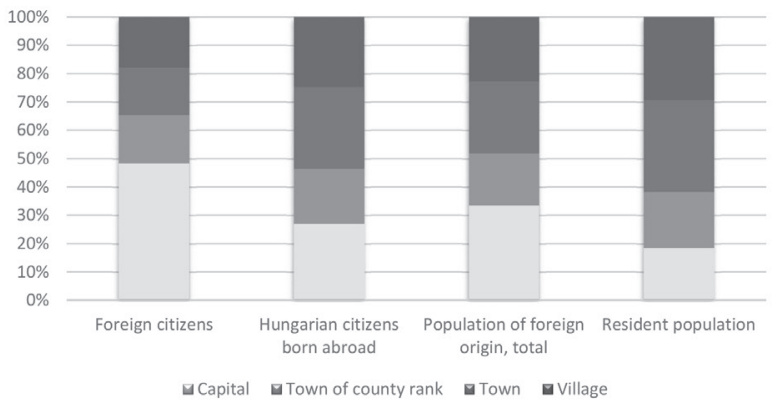

Source: Author's calculation, based on HCSO database

The Lake Balaton region is mainly chosen by German, Austrian, Dutch, and Swiss pensioners; older people usually choose this area because their pensions provide them with greater purchasing power, as well as recreational opportunities and the value of a natural environment. In many cases, foreigners come as tourists before migrating (Kincses et al. 2014), and then migrate already having detailed information about the target areas. The volume of elderly migration increased significantly in the period under review.

Figure 5 Proportion of population of foreign origin per 100 inhabitants

\section{1}

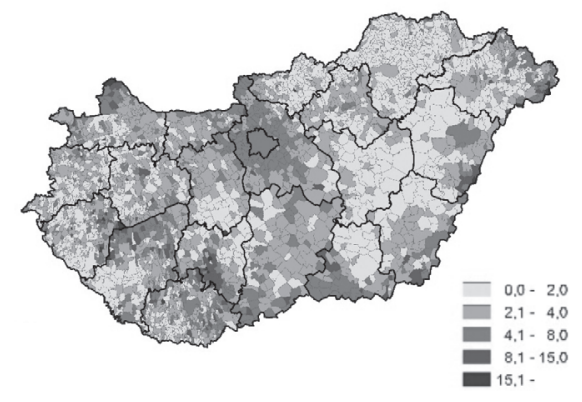

\section{7}

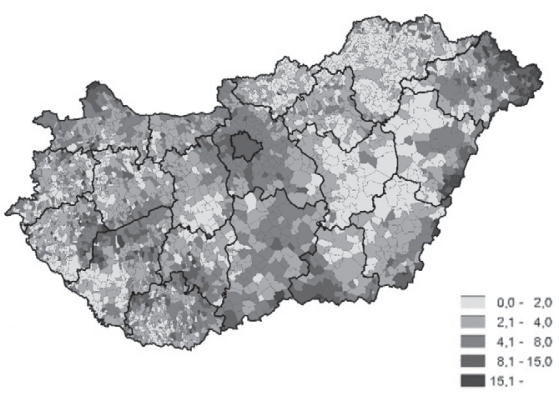

Source: Author's calculation, based on HCSO database 


\section{THE TERRITORY SOURCES OF INTERNATIONAL MIGRATION TO HUNGARY FROM THE CARPATHIAN BASIN}

\section{Identifying source territories}

Using official statistics, the data links and classifications described in the second section allow for the elimination of this omission, facilitating examination of wider migration processes, since demographic processes are not worth examining only within the current borders of the country. Since for the examination of the effects of emigration it is not relevant whether someone is a foreigner or lives in Hungary as a Hungarian citizen, I deal with the foreignorigin population collectively.

Migration processes are examined below according to the original place of birth and the demographic, sociological, and labor-market variables of migrants. The territorial level of the study is the county level (NUTS3). The latter territorial classification is applied in most neighboring countries, with the exception of Ukraine, where no such classification exists. The oblast level is more integrated, while the rajon is more detailed than this (Mezencev 2010). Since within Ukraine Transcarpathia plays the most notable role, I have used the most fine-grained classification.

In 2017, the population of foreign origin from Hungary's neighboring countries living in Hungary was 352,506. Of these, 7,131 were born in Hungary, and 560 of them had never seen daylight in their country of nationality (for example, Romanian citizens born in Germany, or Serbian citizens born in Sweden). Thus, 344,815 people who were born in one of the countries neighboring Hungary (regardless of nationality) were living in Hungary in 2017. This represents a 24\% increase compared to 2011.

On January 1, 2011, the majority of the population born abroad but at that time living in Hungary had been born in the counties of Mures (27,879 persons), Bihor (27,374 persons), Hargita (26,439 persons), Cluj (21,667 persons), Satu Mare (17,102 persons), in the Nitriansky kraj (13,742 persons), Covasna county $(10,821$ persons), Berehove rajon (9,301 persons), Severnobački okrug $(8,877$ persons), Uzhhorod rajon (7,958 persons) and the Severnobanatski okrug (7,668 persons). These are the Romanian, Transcarpathian, Vojvodina, and Slovak areas where the proportion of Hungarian nationals is high (Kapitány 2015).

By 2017, only the order of the five major Transylvanian counties had changed (Hargita 35,613, Mures 32,433, Bihor 31,587, Satu Mare 20,075, and Cluj 19,540). The rest of the major source areas were Berehove rajon $(19,429$ persons), Covasna County (17,021), Severnobački okrug (12,769), Uzhhorod 
rajon $(12,410)$, Severnobanatski okrug $(11,687)$, Vynohradiv rajon $(11,628)$, and the Nitriansky kraj $(10,286){ }^{4}$

Figure 6 Population of foreign origin from neighboring countries living in Hungary by birth region ${ }^{5}$
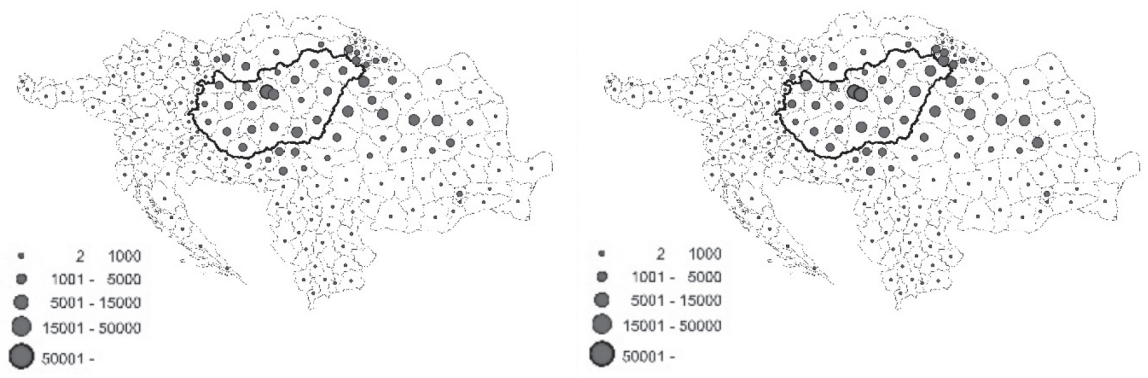

Source: Author's calculation, based on HCSO database

From the major source regions, the areas where the "emitting" (sending) role strengthened for the years under review were Transcarpathia (at the level of rajons: Vynohradiv: 259\%, Berehove: 209\%, Mukachevo: 177\%, Khust: 159\%, Uzhhorod: $156 \%$, Tiachiv: $131 \%$ ), as well as Bacau (243\%) and Covasna (157\%) counties.

For the following, more detailed, examinations, I have organized the regions of the surrounding countries into groups. I divided Romania's counties into three parts. The first group is located near the border counties (Arad, Bihor, Caras Severin, Maramures, Salaj, Satu Mare, Timis); the second group is composed of the Transylvanian regions (Alba, Bistrita Nasaud, Brasov, Cluj, Covasna, Hargita, Mures, Hunedoara, Sibiu), and the third is composed of other individual territories.

I have distinguished between three different groups in the case of Ukraine, covering all the Ukrainian settlements in a complete but disjointed mode. Into

4 Table 3 in the study contains the number of Hungarians living in the Carpathian Basin by county.

5 The map displays the places of birth in the neighboring countries of citizens living in Hungary, while in the Hungarian parts one can see those who live in a given county but were born in a nearby country (I have used this approach on all the following maps included in this paper). 
the first class, I categorized the districts near the border: the rajons of Berehove, Mukachevo, Vynohradiv and Uzhhorod. The second group includes the Carpathian mountain area, the mostly inhabited by Rusyn rajons of Velykyi Bereznyi and Perechyn, and the region of Boykos - including the rajon of Svaliava, Volovets, Irshava and Mizhhiria -, in addition to the Hutsul region - Rakhiv district - and the Maramures Basin - the Khust and Tiachiv rajons. The third group consists of Ukraine's internal territory, beyond the Carpathian Mountains.

I also divided Serbia into three units. The first category covers Severnobački, Severnobanatski, and Zapadnobački okrugs, all near the border; the second includes the areas of Južnobački, Južnobanatski and Sremski, while the third group consists of other territories, namely Serbian territories outside of Vojvodina.

I divided residences in Slovakia into two parts. The first includes the krajs near the border (Banskobystrický, Nitriansky, Trnavský and Košický); the second covers the rest of the areas (Prešovský, Bratislavský, Trenčiansky, Žilinský).

I distinguished three categories in Austria. The first is Burgenland, the second covers the regions near the border (Vienna, Lower Austria, and Styria), and the third includes the rest of the territory (Tirol, Salzburg, Vorarlberg, Carinthia, and Upper Austria). I used two categories for Croatia and Slovenia, respectively. In Croatia, the first group includes the border counties (Osječko-baranjska, Koprivničko-križevačka, Međimurje, Virovitičko-podravska, Vukovarskosrijemska), and the second the rest of the territory. In Slovenia, the first group includes Pomurska County by the border, while the second includes the rest of the territory.

\section{Demographic, labor market, and sociological characteristics of the population of foreign origin in relation to birth regions}

The data for both 2011 and 2017 confirm that the average age of foreign citizens living in Hungary from western Slovakia, southern Serbia, and Romania (not including Transylvania) is among the highest, in many cases well above the 50year average.

The proportion of people of over the age of 65 is highest in relation to those arriving from Slovakia, Romania (not including Transylvania), and the western provinces of Austria. The latter case is due to the higher purchasing power of pensions and the search for a more natural living environment (for example, Hévíz) (Illés 2008). Behind the other cases is the aging of immigrants, as well as the opportunity to access a higher level of social and health care in Hungary. The population aged 65 years or older arriving from Ukraine numbers more than 8,000. According to Hungarian law, these individuals are eligible to receive 
their pension according to Hungarian pension calculations, resulting in larger pensions than they would receive in Ukraine (Gellérné et al. 2005). The greatest proportion of young people arrive from Austria, Ukraine, and Slovenia. This is partially explained by education-oriented migration. In the case of Austria, it is important to mention that the statistics are likely to capture the immigration of Hungarian children born abroad whose families had previously emigrated from Hungary, the former who later returned with their young children.

The proportion of working age people (from 25 to 64 years old) is largest with regard to those arriving from Transcarpathia, Transylvania, and Northern Vojvodina. It is generally true that among the migrants born near the border, more tend to be retired or young people, while migrants arriving from larger distances are more typically of working age.

Figure 7 Population of foreign origin from neighboring countries living in Hungary by birth region and average age

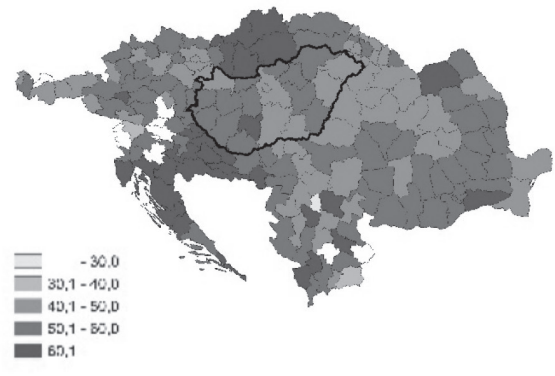

2011

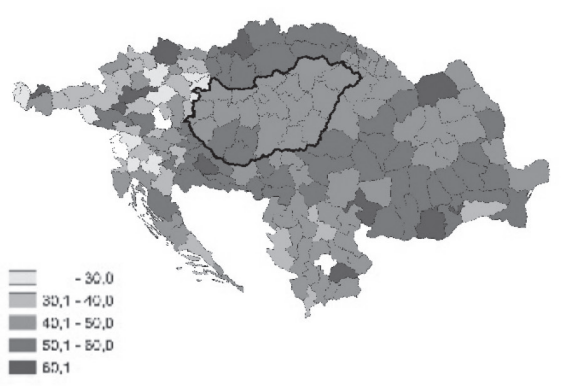

2017

Source: Author's calculation based on HCSO database

The main feature of international migration to Hungary is that the majority of the immigrating population are either of Hungarian nationality or are native speakers of Hungarian. In 2011, the proportion of non-Hungarian native speakers from the countries of the Carpathian Basin was 14\%; in 2017, this figure was around 3\%. Behind this change may be the assimilation of non-Hungarian ethnic groups (namely, some of those who were already living in Hungary in $2011 \mathrm{did}$ not declare themselves ethnically Hungarian at that time, but did so in 2017). It is possible to identify the demographic processes behind the phenomenon as existing in the period before 1918. The proportion of non-Hungarian native speakers is higher in relation to those arriving from Ukraine (not including the Transcarpathian regions), Northern Slovakia, Serbia (not including Vojvodina), 
as well as Austria, Croatia, and Slovenia. In the case of Ukraine, the major proportion can be linked to the Russian-Ukrainian conflict that has been ongoing since 2014, the economic and social crisis, and uncertainty (Karácsonyi et al., 2014).

Figure 8 Distribution of population of foreign origin from neighboring countries living in Hungarv hv age groun and region of hirth. 2017

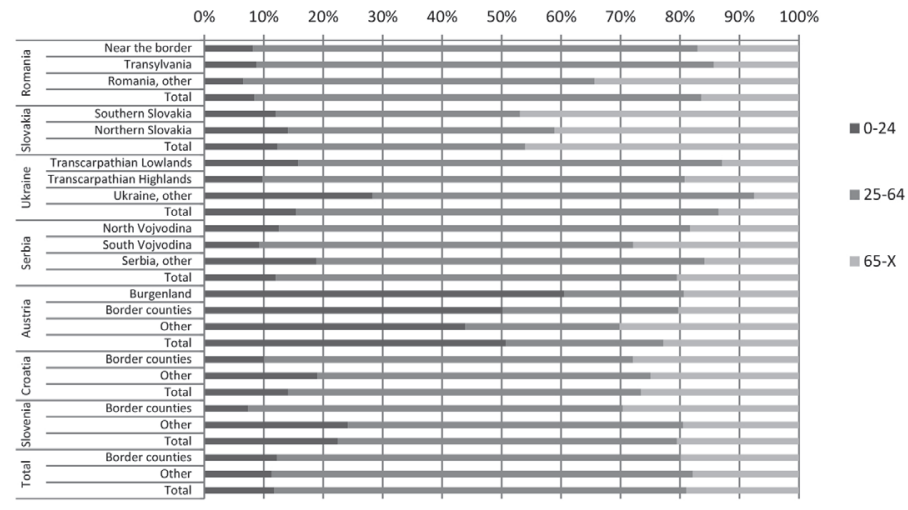

Source: Author's calculation based on HCSO database

Figure 9 Population of foreign origin from neighboring countries living in Hungary by region of birth and proportion of Hungarian native speakers

2011

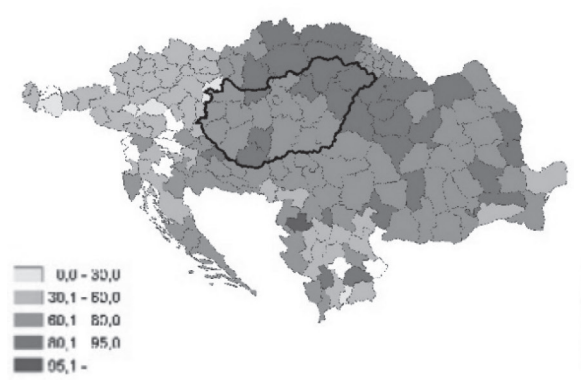

2017

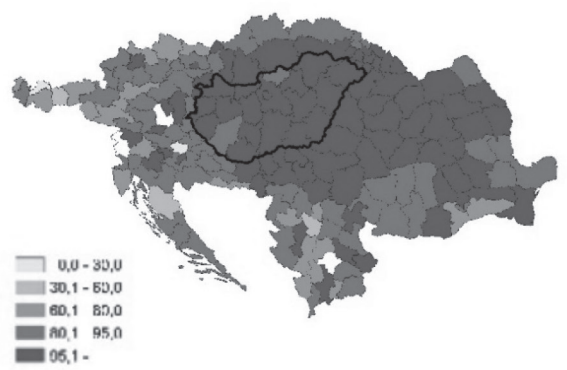

Source: Author's calculation based on HCSO database 
Figure 10 Population of foreign origin from neighboring countries living in Hungary by native language and region of birth, 2017

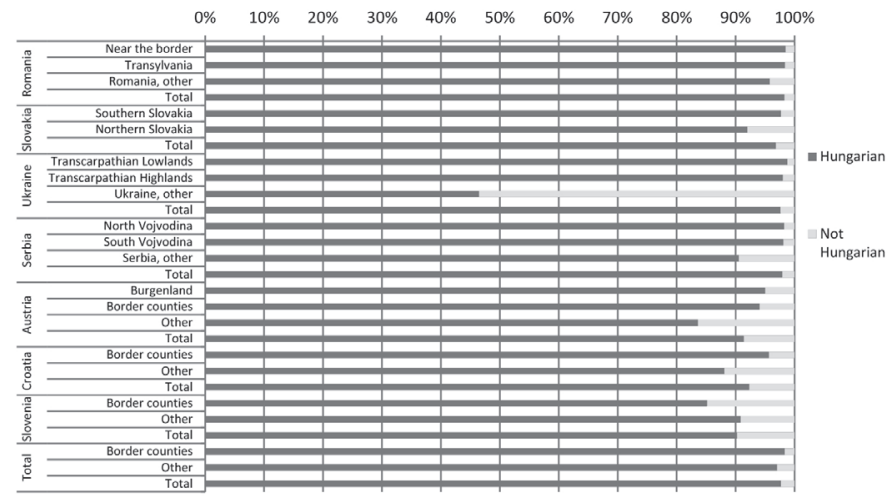

Source: Author's calculation, based on HCSO database

In Hungary, international migrants have, on average, a higher level of education than the resident population (Rédei 2007). This is equally true of the citizens of neighboring countries. In 2011, more than half of the resident population aged 25 or older in Hungary had at least graduated from high school; this proportion was $68 \%$ for those arriving from neighboring countries. Educational qualifications are constantly increasing; however, there are no major territorial differences in the regional distribution of degrees.

Figure 11 Population of foreign origin from neighboring countries living in Hungary of age 25 or older by higher education and region of birth

2011

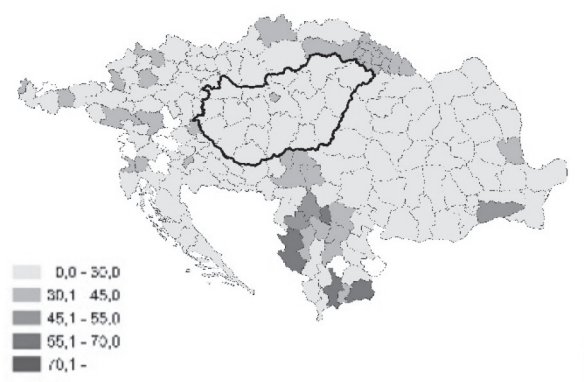

2017

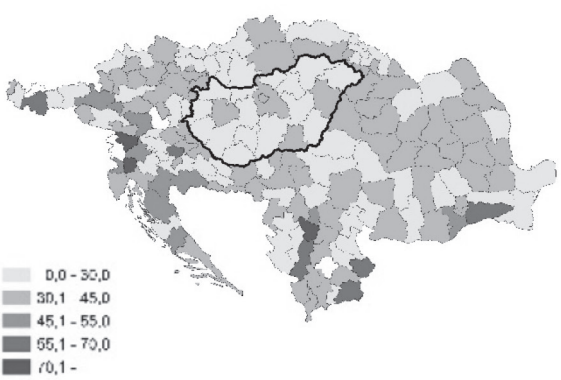

Source: Author's calculation based on HCSO database 
Today, it seems that the decades-old rule that the potential impact area of migration increases along with education has been partly overthrown (Rédei 2007). Nowadays, those with the lowest levels of education participate much more in long-distance migration than their counterparts who migrate from shorter distances.

Figure 12 Population of foreign origin from neighboring countries living in Hungary of age 25 or older by education level and region of birth, 2017

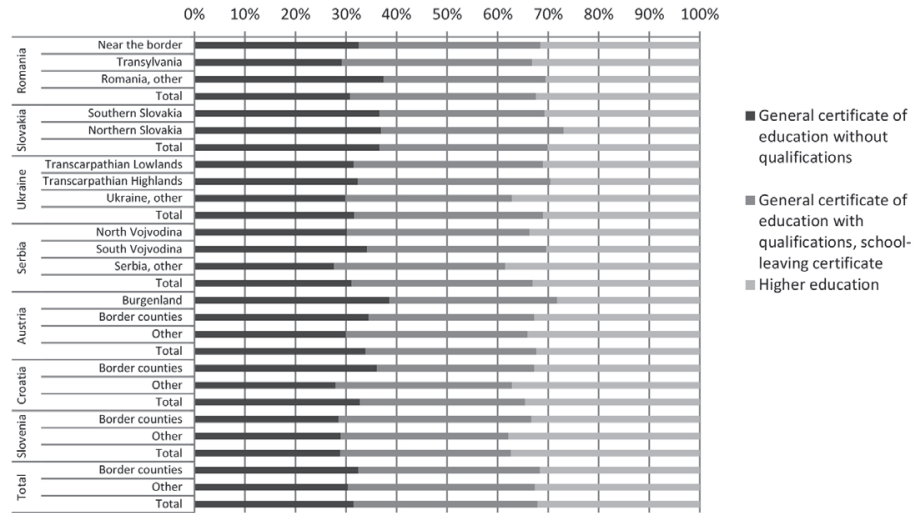

Source: Author's calculation based on HCSO database

Educational qualifications also have a decisive impact on labor-market characteristics. The employment rate for 25 to 64 year-old residents in Hungary born in neighboring countries was $79 \%$ in 2017 . That is to say, more citizens of neighboring countries work than those of the resident population (75.1\%).

According to birth region, those individuals with the highest employment rates are Serbian and Romanian citizens who migrated from areas furthest from the border, and the border regions of Croatia and Slovenia. This can be partly attributed to their higher education levels.

The highest inactivity rates are seen with people originating from Austria and Ukraine (not including Transcarpathia). Many of the former group are still students, or live off their own assets, while in the case of the latter country, many not have been able to enter the labor market force, or perhaps are not legally employed. 
Figure 13 Population of foreign origin from neighboring countries living in Hungary aged 25-64 years old by employment rate and region of birth

$$
2011
$$

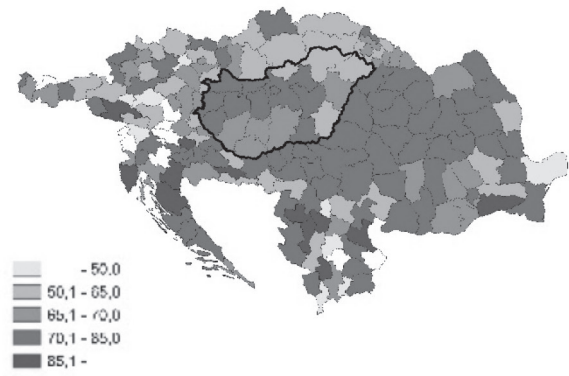

2017

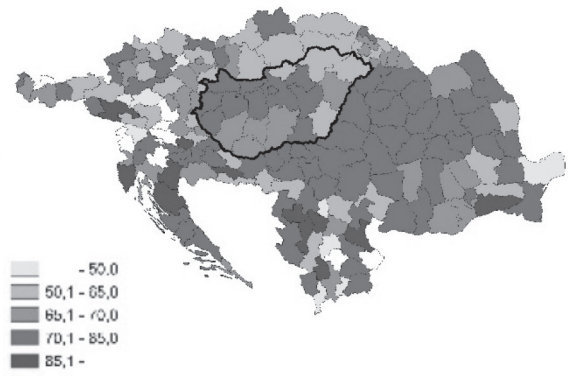

Source: Author's calculation based on HCSO database

Figure 14 Population of foreign origin from neighboring countries living in Hungary aged 25-64 years old by employment and region of birth, 2017

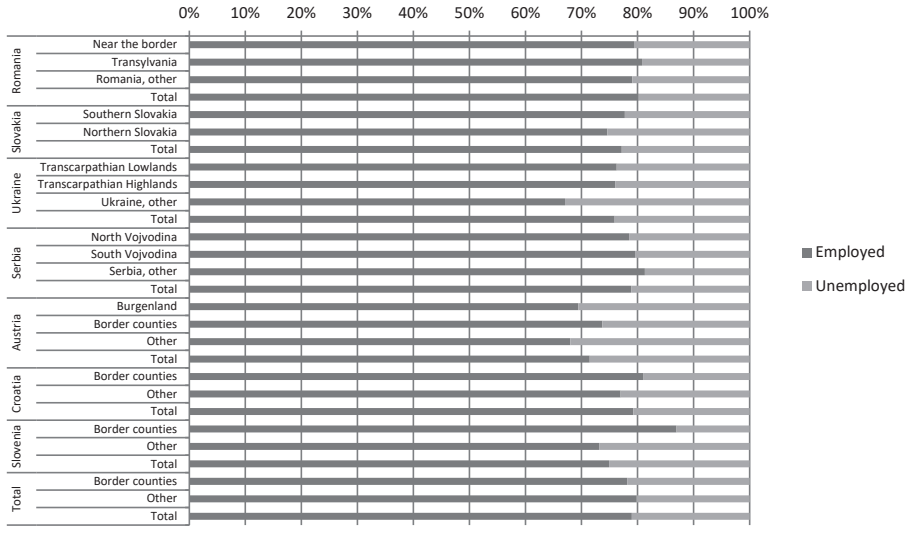

Source: Author's calculation based on HCSO database 


\section{The impact of migration to Hungary on the population of Hungarians in source areas}

The "third demographic disaster" was a turning point in the development of the population of Hungarians in the Carpathian Basin. After the Great War, due to artificial intervention in domestic population trends, what had been until then the organic process of population development came to a halt (Tóth 2018). In fact, the present population development of Hungarians in the Carpathian Basin is interrelated with this; it is a mutually supportive dual process. One element of this process was continuous population development determined by the fertility of the now ethnically unified Hungarians, modified by mortality. The other element of the process consisted of members of other populations assimilating into the Hungarian population. Within the framework of the "Hungarian Empire," the results of both processes ensured the thriving growth of the Hungarian population beyond the natural rate, which enabled Hungarians to overcome their demographic disasters by 1918 .

The role of international migration in population replacement changed after 1918. As a result, the majority of "foreigners" migrating to the country (namely, the migration of Hungarians living in neighboring countries to Hungary) did not increase the number of Hungarians, but only the number of Hungarians living in Hungary (Tóth 2010, 2018).

My aim is to explore how migration into Hungary has shaped and continues to shape Hungarian ethnic spatial structure, the territorial composition of the Hungarian ethnic population, and its proportions in the Carpathian Basin. On the one hand, based on the 2011 population census, I make an estimate at a regional level for those ethnic proportions that would have existed in the neighboring countries in 2011 without migration to Hungary. On the other hand, I calculate how the migration trends between 2011 and 2017 shaped the ethnic structure of Hungarians abroad. I provide an estimate for the changes in the regional ethnic share in 2017 (assuming other ethnicities remained unchanged in number), which took place solely due to migration to Hungary.

The analysis does not cover the migration of Hungarians to neighboring countries; it focuses solely on the migration of the population of those of foreign origin. The 2011 census data of the surrounding countries was the starting point for the estimate. No census has been carried out in Ukraine since 2001;

\footnotetext{
6 The first demographic disaster was the Tatar invasion; the second was the Turkish occupation; and the third was the Trianon Peace Treaty and the "Great War"; while the fourth was caused by the loss of World War II. Following the 1956 Revolution, there was also a significant loss of population, but this was not as measurable as with the four demographic catastrophes listed above.
} 
therefore, only information from 2001 was available. Instead of all of Ukraine, only Transcarpathia was included in the analysis. The set of questions on ethnicity is not mandatory in the censuses of any of these countries (in Austria and Slovenia no such questions are even asked at all), which makes it difficult to draw an accurate picture of the situation. The territorial distribution of the ethnic Hungarian population of the Carpathian Basin in 2011 - the starting point of my estimates - has been calculated according to the estimations in the literature (Molnár et al. 2005; Kiss et al. 2012; Kapitány 2015; Tóth 2018). I relied on a method created by Balázs Kapitány (Kapitány 2015) to determine the 2011 share of ethnic minorities. The essence of this method is adjusting the number of people who declare their nationality by classifying non-respondents proportionately in the given area according to the proportion of those who declare their ethnicity. This process refines the underestimation of proportions of Hungarians in the censuses of the neighboring countries, but even then, the results still underestimate the real number of Hungarians abroad.

The wider applicability of the results of the process is also limited by several factors. On the one hand, methodological differences can be observed in the practice of census-taking in individual states. On the other, Hungarian censuses may overestimate the proportion of the Hungarian ethnic population within the population of foreign origin (in Hungary it is perhaps easier for the former to declare themselves Hungarian). Thus, in the areas of emigration, it is possible to detect a higher number of Hungarian ethnic migrants than the reality. We do not have a precise picture of the assimilation process in Hungary (for example, if someone belonging to the Romanian ethnic group came to Hungary and later became Hungarian).

Table 3 Territorial ethnic proportions and changes in the Carpathian Basin, 2011 and 2017

\begin{tabular}{|c|c|c|c|c|c|c|c|c|c|c|}
\hline 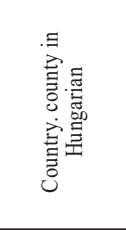 & 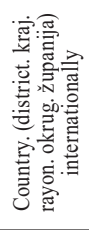 & 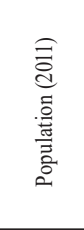 & 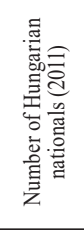 & 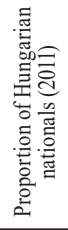 & 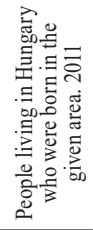 & 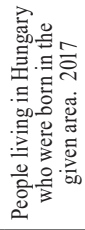 & 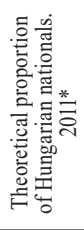 & 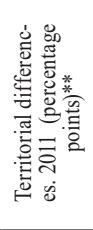 & 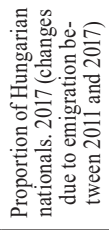 & 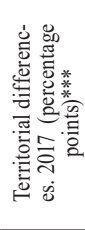 \\
\hline \multicolumn{11}{|c|}{ Romania } \\
\hline Arad & Arad & 430629 & 39298 & 9.1 & 4680 & 6028 & 10.1 & 1 & 8.8 & 0.3 \\
\hline $\begin{array}{c}\text { Besz- } \\
\text { terce-Naszód }\end{array}$ & $\begin{array}{l}\text { Bistrita } \\
\text { Nasaud } \\
\end{array}$ & 286225 & 15091 & 5.3 & 815 & 1119 & 5.5 & 0.2 & 5.2 & 0.1 \\
\hline Bihar & Bihor & 575398 & 147607 & 25.7 & 21936 & 31160 & 28.4 & 2.7 & 24.4 & 1.3 \\
\hline Brassó & Brasov & 549217 & 42880 & 7.8 & 2847 & 4177 & 8.3 & 0.5 & 7.6 & 0.2 \\
\hline
\end{tabular}




\begin{tabular}{|c|c|c|c|c|c|c|c|c|c|c|}
\hline Fehér & Alba & 342376 & 15969 & 4.7 & 1601 & 2123 & 5.1 & 0.4 & 4.5 & 0.2 \\
\hline Hargita & Harghita & 310867 & 268555 & 86.4 & 21055 & 35102 & 87.3 & 0.9 & 85.7 & 0.7 \\
\hline Hunyad & Hunedoara & 418565 & 16976 & 4.1 & 3283 & 4411 & 4.8 & 0.7 & 3.8 & 0.3 \\
\hline Kolozs & Cluj & 691106 & 111420 & 16.1 & 17362 & 19218 & 18.2 & 2.1 & 15.9 & 0.2 \\
\hline Kovászna & Covasna & 210177 & 157062 & 74.7 & 8488 & 16740 & 75.7 & 1 & 73.7 & 1 \\
\hline Krassó-Szörény & $\begin{array}{c}\text { Caras } \\
\text { Severin }\end{array}$ & 295579 & 3297 & 1.1 & 275 & 440 & 1.2 & 0.1 & 1.1 & 0 \\
\hline Máramaros & Maramures & 478659 & 34945 & 7.3 & 4199 & 5276 & 8.1 & 0.8 & 7.1 & 0.2 \\
\hline Maros & Mures & 550846 & 212801 & 38.6 & 22458 & 31875 & 41 & 2.4 & 37.6 & 1 \\
\hline Szatmár & Satu Mare & 344360 & 121161 & 35.2 & 13922 & 19790 & 37.7 & 2.5 & 34.1 & 1.1 \\
\hline Szeben & Sibiu & 397322 & 11683 & 2.9 & 1374 & 1643 & 3.3 & 0.4 & 2.9 & 0 \\
\hline Szilágy & Salaj & 224384 & 53011 & 23.6 & 5219 & 8337 & 25.4 & 1.8 & 22.5 & 1.1 \\
\hline Temes & Timis & 683540 & 38812 & 5.7 & 3387 & 3806 & 6.1 & 0.4 & 5.6 & 0.1 \\
\hline $\begin{array}{r}\text { Transylvania. H } \\
\text { Romanian bor }\end{array}$ & $\begin{array}{l}\text { Hungarian/ } \\
\text { rderland }\end{array}$ & 6789250 & 1290568 & 19.0 & 132901 & 191245 & 20.6 & 1.6 & 18.3 & 0.7 \\
\hline Romania. o & other & 19897257 & 17339 & 0.1 & 8182 & 10814 & 0.1 & 0 & 0.1 & 0 \\
\hline Romania & total & 20121641 & 1307907 & 6.5 & 141083 & 202059 & 7.2 & 0.7 & 6.2 & 0.3 \\
\hline & & & & Slov & & & & & & \\
\hline Besztercebánya & $\begin{array}{c}\text { Banskoby- } \\
\text { strický }\end{array}$ & 660563 & 72752 & 11.0 & 3192 & 3181 & 11.4 & 0.4 & 11 & 0 \\
\hline Eperjes & Prešovský & 814527 & 695 & 0.1 & 259 & 318 & 0.1 & 0 & 0.1 & 0 \\
\hline Kassa & Košický & 791723 & 80444 & 10.2 & 3927 & 3980 & 10.6 & 0.4 & 10.2 & 0 \\
\hline Nagyszombat & Trnavský & 554741 & 129997 & 23.4 & 4694 & 4302 & 24.1 & 0.7 & 23.5 & -0.1 \\
\hline Nyitra & Nitriansky & 689867 & 182386 & 26.4 & 11369 & 10056 & 27.6 & 1.2 & 26.6 & -0.2 \\
\hline Pozsony & $\begin{array}{c}\text { Brati- } \\
\text { slavský }\end{array}$ & 602436 & 25710 & 4.3 & 2860 & 2861 & 4.7 & 0.4 & 4.3 & 0 \\
\hline Trencsén & $\begin{array}{c}\text { Trenčian- } \\
\text { sky }\end{array}$ & 594328 & 858 & 0.1 & 344 & 310 & 0.2 & 0.1 & 0.2 & -0.1 \\
\hline Zsolna & Žilinský & 688851 & 595 & 0.1 & 83 & 191 & 0.1 & 0 & 0.1 & 0 \\
\hline Slovakia to & total & 5397036 & 493437 & 9.1 & 26728 & 25199 & 9.6 & 0.5 & 9.2 & -0.1 \\
\hline \multicolumn{11}{|c|}{ Serbia } \\
\hline Észak-Bácska & $\begin{array}{c}\text { Severno- } \\
\text { bački }\end{array}$ & 186906 & 80242 & 42.9 & 6247 & 12530 & 44.8 & 1.9 & 40.9 & 2 \\
\hline Észak-Bánát & $\begin{array}{c}\text { Severnoba- } \\
\text { natski }\end{array}$ & 147770 & 72511 & 49.1 & 5330 & 11510 & 50.8 & 1.7 & 46.8 & 2.3 \\
\hline Dél-Bácska & Južnobački & 615371 & 50347 & 8.2 & 4086 & 6222 & 8.8 & 0.6 & 7.9 & 0.3 \\
\hline Közép-Bánát & $\begin{array}{c}\text { Srednjeba- } \\
\text { natski }\end{array}$ & 187667 & 24779 & 13.2 & 1144 & 2027 & 13.7 & 0.5 & 12.8 & 0.4 \\
\hline Nyugat-Bácska & $\begin{array}{c}\text { Zapadno- } \\
\text { bački }\end{array}$ & 188087 & 18493 & 9.8 & 2076 & 3313 & 10.8 & 1 & 9.2 & 0.6 \\
\hline
\end{tabular}




\begin{tabular}{|c|c|c|c|c|c|c|c|c|c|c|}
\hline Dél-Bánát & $\begin{array}{c}\text { Južnoba- } \\
\text { natski }\end{array}$ & 293730 & 13882 & 4.7 & 494 & 843 & 4.9 & 0.2 & 4.6 & 0.1 \\
\hline Szerémség & Sremski & 312278 & 3987 & 1.3 & 43 & 99 & 1.3 & 0 & 1.3 & 0 \\
\hline Vajdaság & Vojvodina & 1931809 & 264241 & 13.7 & 19420 & 36544 & 14.5 & 0.8 & 12.9 & 0.8 \\
\hline \multicolumn{2}{|c|}{ Serbia. other } & 5255053 & 12763 & 0.2 & 495 & 1513 & 0.2 & 0 & 0.3 & 0.1 \\
\hline \multicolumn{2}{|c|}{ Total Serbia } & 7186862 & 277004 & 3.9 & 19915 & 38057 & 4.1 & 0.2 & 3.6 & 0.3 \\
\hline \multicolumn{11}{|c|}{ Transcarpathia } \\
\hline Beregszász & Berehove & 80616 & 53948 & 66.9 & 6440 & 19200 & 69.4 & 2.5 & 60.7 & 6.2 \\
\hline Huszt & Khust & 128824 & 5511 & 4.3 & 1019 & 2446 & 5 & 0.7 & 3.2 & 1.1 \\
\hline Ilosva & Irshava & 100905 & 114 & 0.1 & 216 & 650 & 0.3 & 0.2 & -0.3 & 0.4 \\
\hline Munkács & $\begin{array}{l}\text { Mukache- } \\
\text { vo }\end{array}$ & 183080 & 19846 & 10.8 & 2630 & 7199 & 12.1 & 1.3 & 8.6 & 2.2 \\
\hline Nagyberezna & $\begin{array}{c}\text { Velykyi } \\
\text { Bereznyi }\end{array}$ & 28211 & 15 & 0.1 & 74 & 126 & 0.3 & 0.2 & -0.1 & 0.2 \\
\hline Nagyszőlős & $\begin{array}{c}\text { Vynohrad- } \\
\text { iv } \\
\end{array}$ & 117957 & 30874 & 26.2 & 3035 & 11503 & 28 & 1.8 & 20.5 & 5.7 \\
\hline Ökörmező & Mizhhiria & 49890 & 8 & 0.0 & 161 & 223 & 0.3 & 0.3 & -0.1 & 0.1 \\
\hline Perecseny & Perechyn & 32026 & 78 & 0.2 & 90 & 175 & 0.5 & 0.3 & 0 & 0.2 \\
\hline Rahó & Rakhiv & 90945 & 2929 & 3.2 & 298 & 653 & 3.5 & 0.3 & 2.8 & 0.4 \\
\hline Szolyva & Svaliava & 54869 & 383 & 0.7 & 167 & 327 & 1 & 0.3 & 0.4 & 0.3 \\
\hline Técső & Tiachiv & 171850 & 4991 & 2.9 & 1161 & 2252 & 3.6 & 0.7 & 2.3 & 0.6 \\
\hline Ungvár & Uzhhorod & 189967 & 32794 & 17.3 & 5396 & 12257 & 19.5 & 2.2 & 14.2 & 3.1 \\
\hline Volóc & Volovets & 25474 & 25 & 0.1 & 88 & 162 & 0.4 & 0.3 & -0.2 & 0.3 \\
\hline Transcarpa & hia total & 1254614 & 151516 & 12.1 & 20775 & 57173 & 13.5 & 1.4 & 9.4 & 2.7 \\
\hline \multicolumn{11}{|c|}{ Austria } \\
\hline Örvidék**** & $\begin{array}{l}\text { Burgen- } \\
\text { land**** }\end{array}$ & 286215 & 10000 & 3.5 & 336 & 2188 & 3.6 & 0.1 & 2.9 & 0.6 \\
\hline Austria. & other & 8349150 & 7270 & 0.1 & 1945 & 7581 & 0.1 & 0 & 0 & 0.1 \\
\hline Austria & otal & 8635365 & 17270 & 0.2 & 2281 & 9769 & 0.2 & 0 & 0.1 & 0.1 \\
\hline \multicolumn{11}{|c|}{ Croatia } \\
\hline Észak-Baranya & $\begin{array}{l}\text { Osječko- } \\
\text { baranjska }\end{array}$ & 305032 & 8532 & 2.8 & 764 & 762 & 3 & 0.2 & 2.8 & 0 \\
\hline Croatia. & ther & 3879775 & 5516 & 0.1 & 1469 & 1476 & 0.2 & 0.1 & 0.1 & 0 \\
\hline Croatia. & total & 4184807 & 14048 & 0.3 & 2233 & 2238 & 0.4 & 0.1 & 0.3 & 0 \\
\hline \multicolumn{11}{|c|}{ Slovenia } \\
\hline Muramente & Pomurska & 118988 & 4000 & 3.4 & 16 & 46 & 3.4 & 0 & 3.3 & 0.1 \\
\hline \multicolumn{2}{|c|}{ Slovenia. other } & 1955192 & 2243 & 0.1 & 354 & 417 & 0.1 & 0 & 0.1 & 0 \\
\hline
\end{tabular}




\begin{tabular}{|c|c|c|c|c|c|c|c|c|c|}
\hline Slovenia total & 2074180 & 6243 & 0.3 & 370 & 463 & 0.3 & 0 & 0.3 & 0 \\
\hline \multicolumn{10}{|c|}{ Hungary } \\
\hline Hungary total & 9937628 & 9741112 & 98.0 & - & - & 98.0 & - & - & - \\
\hline \multicolumn{10}{|c|}{ Carpathian Basin } \\
\hline $\begin{array}{c}\text { Total Carpathian Basin (the } \\
\text { former Hungarian Kingdom. } \\
\text { without the former Croatian } \\
\text { Kingdom) }\end{array}$ & 26020572 & 11963406 & 46.0 & 200940 & 313157 & 46.0 & - & - & - \\
\hline $\begin{array}{l}\text { *: The theoretical rates a } \\
\text { Hungary were non-exister } \\
* *: \text { The difference in the p } \\
\text { ***: The differences in eth } \\
* * * * \text { : The study focuses } \\
\text { migration of Hungarian-b } \\
\text { calculations by Kapitány }\end{array}$ & $\begin{array}{l}\text { re those eth } \\
\text { tt. } \\
\text { roportions } \\
\text { inic proport } \\
\text { solely on t } \\
\text { orn Hungal } \\
\text { Balázs (2015 }\end{array}$ & $\begin{array}{l}\text { inic propor } \\
\text { without em } \\
\text { tions betwe } \\
\text { the migrati } \\
\text { trians migrc } \\
\text { 5). }\end{array}$ & $\begin{array}{l}\text { ons th } \\
\text { ration } \\
\text { n } 2011 \\
n \text { of th } \\
\text { ing to }\end{array}$ & $\begin{array}{l}\text { t would } \\
\text { and the } \\
\text { (adjusted } \\
\text { e popula } \\
\text { neighbor }\end{array}$ & $\begin{array}{l}\text { be accur } \\
\text { actual et } \\
\text { d) and } 20 \\
\text { tion of } f \\
\text { ing coun }\end{array}$ & $\begin{array}{l}\text { te in } \\
\text { nic s } \\
7, \text { tal } \\
\text { reign } \\
\text { ries. }\end{array}$ & & $\begin{array}{l}\text { n int } \\
\text { es no } \\
\text { sted }\end{array}$ & \\
\hline
\end{tabular}

In 2011, 26 million people were living in the Carpathian Basin (on the territory of the historic Hungarian Kingdom, not including the former Croatian Kingdom); among them, 12 million $-46 \%$ of the people living there - declared themselves Hungarian. In 2011, 201,000 and in 2017, 313,000 (13\% of Hungarians living abroad) individuals of Hungarian ethnicity who were born in the other countries of the Carpathian Basin were living in Hungary.

If we look at the entirety of international migration movements in Hungary in what was the country's territory prior to the Treaty of Trianon, we find that about half of the movement would count as internal migration. The consequences of the peace agreements that ended World War I and World War II and cross-border linguistic and cultural relations are still dominant in the migration processes of the Carpathian Basin (Tóth 2005). The data confirms that the migration trend that was occurring before World War I continued, whereby movements from the periphery to the center of the country were characteristic.

It is important to emphasize that migration from neighboring countries to Hungary has a significant influence on the ethnic spatial structure: locally, in the areas of emigration, schooling, labor market, cultural and social opportunities decrease in proportion to the number of Hungarians; ethnic relationships may narrow, and with scattering, assimilation may appear in parallel or become accelerated (Kocsis 2002, 2003, 2006, 2015; Kocsis et al., 2015; Tóth 2018).

According to 2011 data, the proportion of those with Hungarian ethnicity in Transcarpathia decreased mostly due to migration to Hungary (the latter $12.1 \%$ would have been $13.5 \%$ had 21,000 people not chosen to leave the region). In Transcarpathia, the rajons of Berehove and Uzhhorod were the most affected (the proportion of those with Hungarian ethnicity declined by 2.5 and 1.8 percentage points, respectively). 
According to the previous census, without migration to Hungary, 21\% of Transylvania's population would be Hungarian; taking into account migration activity, the proportion is now 19\%. The most affected counties are Bihor (a 2.7 percentage point difference), Satu Mare (2.5), Mures (2.4), Cluj (2.1). Fifty per cent of Transylvania's Hungarians live in these territories.

In Slovakia in 2011, the proportion of Hungarians recorded in the previous census was $9.1 \%$; without emigration, we would have seen a half-percentage point increase, to $9.6 \%$. Here the biggest drop was in Nitriansky kraj (by 1.2 percentage points). In 2011, 11,000 people born there were already living in Hungary.

In the cases of Austria, Slovenia, and Croatia, there has been no significant change in ethnic spatial structure linked to the migration of the born-abroad Hungarian population. At the same time, nearly 100,000 Hungarians are working for our neighbor in the West, according to Austrian social security data.? A minority of this group emigrated from Hungary, while a larger portion were daily commuters. Thus, the overall presence of Hungarian nationals in Austria increased in the period under review.

Examining the period since 2011, it can be concluded that the decline of Transcarpathian Hungarians in the Carpathian Basin as a result of emigration is proportionately the most rapid. In 2017, the proportion of Hungarians was estimated at $9.4 \%, 2.7$ percentage points fewer than the previous figure. The proportion of Hungarians in the Berehove rajon stayed at barely above $60 \%$, in comparison to $66.9 \%$ in 2011 , if we assume that the share of other ethnicities remained unchanged. At the same time, the relatively favorable demographic situation of Hungarians living in Transcarpathia and emigration in general tended to dampen the ethnic structural shift (Karácsonyi et al., 2014).

In Romania, according to estimates for 2017, the proportion of Hungarians decreased to $6.2 \%$ from $6.5 \%$ in 2011 . This process mostly affected Bihor county, where the proportion of Hungarians declined to $24.4 \%$, while according to the 2011 census, the proportion was over $25.7 \%$.

Due to steady emigration flow from Severnobački and Severnobanatski, the proportion of ethnic Hungarians in Vojvodina may have decreased from 13.7\% in 2011 to $12.9 \%$ in 2017.

At the same time, movements of Hungarians from Slovakia into Hungary stopped; instead, return migration was characteristic of this period. As such, the ethnic structure remained unchanged for 2017. The same holds true for the other countries under analysis that have not been mentioned so far.

$7 \mathrm{http} / /$ www.hauptverband.at/cdscontent/?contentid=10007.754024\&viewmode=content 


\section{SUMMARY}

International migration into Hungary is markedly differentiated into two parts: a global migration effect, and flows between Hungary and its neighboring countries, which date back a long time. The main characteristic of international migration in Hungary is that the largest part of the immigrant population is of Hungarian nationality or speaks Hungarian as their native language. The strength of the linguistic and cultural relations extending beyond the border are the outcome of the peace treaties that ended World War I and World War II.

The reproduction of minorities living in neighboring countries is not just a matter of natural demographic processes. Migration also plays a significant role. Those arriving to Hungary reduce the numbers of the Hungarian population in the place of emigration, where in most cases, regardless of this factor, population loss is also taking place due to natural demographic causes. In turn, where the number of Hungarians is growing, migration in these cases eliminates this growth, at least in part. On the other hand, migration, an age-specific process, influences the socio-economic progress of the source territories through indirect effects (in relation to dependency rates, mean age, economic activity rates, etc.). Migration to Hungary from the other countries of the Carpatian-Basin does not change the total number of Hungarians in the Carpathian Basin in the short term. However, in the long term the number of the latter number may decline, since migration has a significant influence on ethnic spatial structure.

Population movements in the late 1980s and early 1990s made it clear that the demographic processes taking place in the Hungarian linguistic community - despite the fragmentation that occurred in 1918, and the nearly 100-yearold process of "distributed development" - can only be fully understood if we examine them together, as a single process. It is important to recognize that demographic processes inside and outside of the current border are similar in nature. Therefore, what we see happening in terms of demographic processes in Hungary is only a part of the wider demographic change of the Hungarian language community, but it is not the same. The target might thus not only be stopping the shrinking of the Hungarian population in Hungary, but also in the Carpathian Basin too. Achieving this is not an easy task, as it may not be in line with the national interest of neighboring countries.

The migration processes described in this study have a significant impact on the ethnic spatial structure and numbers of Hungarians in the Carpathian Basin if the numbers of other ethnic groups do not decrease in a similar fashion to that of the Hungarians. Increasing the number of people who stay in their home country and the number of return migrants, along with the fertility rates of local Hungarians could all be partial solutions to the problem. In this way, it may 
be realistic to increase the proportion of Hungarians in the Carpathian Basin to over $50 \%$ again. Currently, the biggest barrier to this process is population loss, which affects the Hungarian population of the Carpathian Basin due to low fertility and high mortality rates.

\section{REFERENCES}

Bálint, Lajos - Obádovics, Csilla (2017), "Belföldi vándorlás", In.: Monostori Judit - Öri Péter - Spéder Zsolt, eds. Demográfiai portré 2018, KSH NKI, pp: 217-236.

Blaskó, Zsuzsa - Gödri, Irén (2016), “A Magyarországról kivándorlók társadalmi és demográfiai összetétele”, In: Blaskó Zs., Fazekas K., eds. Munkaerőpiaci tükör 2015. MTA Közgazdaság- és Regionális Tudományi Kutatóközpont Közgazdaságtudományi Intézet, Budapest, 59-68.

Dövényi, Zoltán (2011), “A Magyarországot érintő nemzetközi vándorlás területi aspektusai”, In: Tarrósy I., Glied V., Keserü, D. eds. Pécs: Publikon Kiadó, 2011. pp. 85-95.

Egedy, Tamás (2017), “A külföldre ingázás statisztikai, demográfiai és területi jellemzői Magyarországon”, Területi Statisztika, Vol. 57. No 4, pp. 385-405. DOI: 10.15196/TS570403

Gárdos, Éva - Sárosi, Annamária - Kincses, Áron - Nagyné Forgács, Eleonóra (2008), "Integrated Database of International Migration Statistics with a Particular Attention to Linking Data Sources", Hungarian Statistical Review Vol. 86. No 12, pp. 75-87.

Gellérné Lukács, É. - Szigeti, B. (2005), Munkavállalási szabályok az EU tagállamaiban az átmeneti idö alatt. KJK Kerszöv, Budapest.

Gödri, Irén (2012), “Nemzetközi vándorlás”, In.: KSH NKI (2012): Demográfiai portré - jelentés a magyar népesség helyzetéröl, Budapest, pp. 137-154.

Hatton, Timothy J. - Williamson, Jeffrey G. (2005), Global Migration and the World Economy: Two Centuries of Policy and Performance, Cambridge Mass., MIT Press

Illés, Sándor (2008), "Indirect estimation on the types of international elderly migration in Hungary", Romanian Review on Political Geography Vol. 8. No 1. pp. 55-63.

Juhász, Attila - Molnár, Csaba - Zgut, Edit (2017), Menekültügy és migráció Magyarországon, Heinrich-Böll-Stiftung e.V., Prága; Political Capital Budapest Kapitány, Balázs (2015), “Külhoni magyar közösségek” In: Demográfiai portré 2015, KSH NKI, pp.: 227-240. 
Karácsonyi, Dávid - Kocsis, Károly - Kovály, Katalin - Molnár, József - Póti, László (2014), "East-West dichotomy and political conflict in Ukraine - Was Huntington right?", Hungarian Geographical Bulletin Vol. 63. No 2, pp. 99134. DOI: $10.15201 /$ hungeobull.63.2.1

Kincses, Áron (2014), “Nemzetközi migrációs körkép Magyarországról a 2011-es népszámlálási adatok alapján", Területi Statisztika, Vol. 54., No 6, pp. 590-605. Kiss, Tamás - Barna, Gergő (2012), Népszámlálás 2011. Erdélyi magyar népesedés a XXI. század első évtizedében Demográfiai és statisztikai elemzés, 43/2012, Nemzeti Kisebbségkutató Intézet, Kolozsvár

Kocsis, Károly (2002), "Etnikai földrajz". In: Tóth J.ed., Általános társadalomföldrajz I., Dialóg Campus Kiadó, Budapest-Pécs,

Kocsis, Károly (2003), A Kárpát-medence etnikai földrajza (896-1989), Manuscript.

Kocsis, Károly - Bottlik, Zsolt - Tátrai, Patrik (2006), Etnikai térfolyamatok a Kárpát-medence határainkon túli régióiban (1989-2002) MTA FKI, Budapest Kocsis, Károly (2015), A Kárpát-medence etnikai térképsorozata (Erdély, Szlovákia, Kárpátalja, Vajdaság, Horvátország, Muravidék, Örvidék, Magyarország), MTA Földrajztudományi Kutatóintézet, Budapest

Kocsis, Károly - Tátrai, Patrik - Agárdi, Norbert -Balizs, Dániel - Kovács, Anikó (2015), A Kárpát-Pannon-térség változó etnikai arculata a 15. század végétől a 21. század elejéig, MTA CSFK Földrajztudományi Intézet, Budapest, 2015 http://www.mtafki.hu/konyvtar/karpat-pannon2015/pdf/Changing Ethnic_Pattern_Carpatho_Pannonian_Area_2015.pdf

Krugman, Paul - Venables, Anthony J. (1996), "Integration, Specialization, and Adjustment", European Economic Review, Vol. 40, pp. 959-968. DOI: 10.1016/0014-2921(95)00104-2

KSH (2017), Új magyar állampolgárok. Változások az egyszerüsített honosítási eljárás bevezetése után, Budapest, p. 64; http://www.ksh.hu/docs/hun/xftp/ idoszaki/pdf/ujmagyarallampolgarok.pdf

Melegh, Attila (2015), "Magyarország a nemzetközi migráció rendszerében". Eszmélet, 2015. június 16. http://eszmelet.hu/melegh-attilamagyarorszag-anemzetkozi-migracio-rendszereben/.

Mezencev, Kosztyantyin (2010), A területi egységek lehatárolásának tökéletesítése Ukrajnában az Európai Unió normái szerint, Területi Statisztika, Vol. 13., No 1, pp. 56-66.

Molnár, József - Molnár D., István (2005), Kárpátalja népessége és magyarsága a népszámlálási és népmozgalmi adatok tükrében, Kárpátaljai Magyar Pedagógusszövetség

Rédei, Mária (2007), Mozgásban a világ, a nemzetközi migráció földrajza, Eötvös Kiadó, Budapest 
Siskáné Szilasi, Beáta - Halász, Levente - Gál-Szabó, Lajos (2017), “A magyar fiatalok erősödő kivándorlási szándékának kiváltó okai és jellemzői”, Tér és Társadalom Vol. 31., No 4, pp.131-147. doi:10.17649/TET.31.4.2885

Tóth, Pál Péter (2005), “A szomszédos országokból bevándorlók lakóhelyi és kulturális jellemzöi”, Korfa 2005/2-3, KSH, NKI pp. 3-7.

Tóth, Pál Péter (2010), “A magyar népességfejlődés meghatározottsága (Múlt, jelen, jövő)", Müvelödés, 2010/04, pp.: 153-163. http://www.muvelodes.ro/ index.php/Cikk?id=956

Tóth, Pál Péter (2018), A Kárpát-medencei magyar népességfejlődés, GlobeEdit. 
